змісту активних методів його опанування та передбачало розробку відповідних дидактичних засобів: програм вивчення тем, методичних рекомендацій щодо їх опанування, навчального посібника, програмних засобів, завдань для самостійної роботи студентів, програми педагогічної (викладацької) практики у вищих навчальних закладах.

Експериментально доведено доцільність упровадження в навчальний процес курсу «Методика викладання педагогічних дисциплін у ВНЗ» за авторською програмою, зміст якої затверджено методичною комісією i вченою радою Державного закладу «Південноукраїнський національний педагогічний університет імені К. Ушинського», та iï позитивний вплив на формування методичної культури майбутніх викладачів.

Отже, інтеграція змісту нормативного курсу «Методика викладання педагогічних дисциплін у вищих навчальних закладах», авторської програми, дидактичних засобів, форм і методів його реалізації слугує розв'язанню проблеми підвищення якості професійно-педагогічної підготовки майбутніх викладачів в умовах магістратури, важливим показником якої $є$ формування і розвиток їхньої методичної культури.

Перспективу подальших наукових розвідок убачаємо в розробленні цілісної технології розвитку методичної культури майбутніх викладачів педагогічних дисциплін в умовах магістратури.

\title{
Література
}

1. Подласый И. П. Педагогика. Новый курс : [учебник для студ. пед. вузов] : В 2 кн. / И. П. Подласый. - М. : Гуманит. изд. центр. ВЛАДОС. - 2000. - Кн. 1 : Общие основы. Процесс обучения. - 576 с. 2. Сластенин В. А. О проектировании содержания высшего педагогического образования / В. А. Сластенин // Преподаватель. - 1999. № 5. - С. 3-9.

\section{ЗДОРОВ' ЯЗБЕРІГАЛЬНА КОМПЕТЕНТНІСТЬ МАЙБУТНІХ УЧИТЕЛІВ ПОЧАТКОВИХ КЛАСІВ: ПОНЯТТЯ І СТРУКТУРА}

Ландо О. А. Здоров'язберігальна компетентність майбутніх учителів початкових класів: поняття і структура.

Статтю присвячено проблемі здоров'язберігальної компетентності майбутніх учителів початкових класів. Розкрито поняття i структуру здоров'язберігальної компетентності майбутніх учителів початкових класів, а також необхідність усвідомленого ставлення майбутніх учителів до здоров'я та здорового способу життя.

Ключові слова: компетенція, компетентність, здоров'язбереження.

Ландо О. А. Здоровьесберегающая компетентность будущих учителей начальных классов: понятие и структура.

Статья посвящена проблеме здоровьесберегающей компетентности будущих учителей начального образования. Раскрыты понятие и структура здоровьесберегающей компетентности будущих учителей начального образования, а также необходимость осознанного отношения будущих учителей к здоровью и здоровому образу жизни.

Ключевые слова: компетенция, компетентность, здоровьесбережение.

Lando O. A. The healthcare competence of primary school teachers: the notion and structure.

The article is devoted to the problem of healthcare competence of primary school teachers. The notion and structure of healthcare competence of future primary school teachers 
are defined. The necessity of the realized attitude towards health and healthy lifestyle is researched.

Key words: competence, competency, healthcare.

Здоров'язбереження $є$ однією 3 найактуальніших проблем сучасності. Міцне здоров’я - основна умова для виконання людиною іiі біологічних і соціальних функцій, фундамент самореалізації особистості.

У сучасному світі в системі ринкових відносин здоров'я людини стає одночасно іiі суб' єктивною цінністю й економічним чинником, що передбачає збереження фахівців професіоналів високого рівня, чиє здоров'я визначає стабільність результативності їхньої праці, а також зміну психологічних настанов на здоров'я як на соціальноекономічне благо. Водночас для системи вищої професійної освіти проблема формування здоров'язберігальної компетентності майбутніх учителів стає все більш актуальною, оскільки освітня система поки що не забезпечує необхідного і достатнього рівня іiї сформованості у випускників вищих педагогічних закладів.

Задля здійснення ефективної освітньої діяльності майбутньому вчителю необхідно бути компетентним у питаннях збереження і зміцнення власного здоров'я та здоров'я учнів, тобто у нього має бути сформованою «здоров'язберігальна компетентність», оскільки наявний стійкий взаємозв'язок між ставленням учителя до власного здоров'я, його потребою у здоровому способі життя, рівнем грамотності в питаннях відновлення всіх аспектів здоров'я і здійсненням відповідного виховного впливу на учнів.

Про сформованість здоров'язберігальної компетентності можна говорити тоді, коли педагог не тільки усвідомлює цінність здоров'я, вмотивований до здоров'язберігальної діяльності, володіє знаннями про здоров'я та здоровий спосіб життя, але й реалізує набуті знання та вміння у практичній педагогічній діяльності.

Компетентність педагога в питаннях здоров'я- важливий складник його професійної культури, що вимагає постійного поповнення психолого-педагогічних та медичних знань 3 питань розроблення та впровадження профілактичних програм $\mathrm{i}$ здоров'язберігальних технологій.

У розроблення теорії професійного здоров'я вчителя значний внесок зробили наукові праці О. Анісімової, М. Малярчука, Г. Мітіної, Л. Мітіної, Ю. Науменко, Г. Никифорова, В. Пахальян, Є. Семьонової, Н. Смирнова та ін; теорії особистості як одній з регуляторів життєвої активності та адаптивності присвячені дослідження таких науковців, як Б. Ананьєв, Л. Мітіна, К. Роджерс, С. Рубінштейн, Г. Сельє та ін.

Компетентність у системі педагогічної освіти $є$ предметом наукових пошуків: I. Беха, С. Гончаренка, І. Зимньої, Н. Кузьміної, А. Маркової, Л. Мітіної, В. Сластьоніна, А. Хуторського та ін. Питанням розвитку професійної компетентності педагога присвячено праці І. Зимньої, М. Лук’янової, Н. Кузьміної, А. Хуторського та ін.

Незважаючи на те, що проблемі професійної компетентності вчителів присвячено значну кількість наукових праць, аналіз наукової літератури свідчить про те, що проблема поняття і структури здоров'язберігальної компетентності майбутніх учителів початкових класів ще залишається недостатньо дослідженою.

Meта cmammi: розкрити поняття і структуру здоров’язберігальної компетентності майбутніх учителів початкових класів як передумову усвідомленого ставлення до здоров'я та здорового способу життя.

За визначенням Всесвітньої організації охорони здоров'я (1991), здоров'я характеризується «станом повного фізичного, душевного і соціального благополуччя, а не тільки відсутністю хвороб і фізичних дефектів» [16]. 
Міцне здоров'я дозволяє належно виконувати людині іï професійні і соціальні функції, є основою самореалізації та саморозвитку особистості.

Сучасний молодий фахівець, який закінчує вищий навчальний заклад повинен володіти компетентностями, що дозволять йому як можна довше зберегти статус здорової людини, щоб більш якісно виконувати свої професійні обов'язки протягом тривалого часу. Питання, пов'язані зі станом здоров'я випускників сучасних вищих навчальних закладів, обговорюються широким колом дослідників $[2 ; 5 ; 11 ; 12 ; 13]$.

В останнє десятиліття й особливо після публікації Національної стратегії розвитку освіти в Україні на період до 2021 року відбувається переорієнтація оцінки результату освіти 3 понять «підготовленість», «освіченість», «загальна культура», «вихованість» на поняття «компетенція» та «компетентність» [6].

Терміни «компетентність» $\mathrm{i}$ «компетенція» набувають все більш широкого поширення в освітньому середовищі, але аналіз психолого-педагогічної літератури (А. Дахін, Д. Єрмаков, І. Зимня, В. Маслов, О. Лебедєв, О. Пометун, С. Сисоєва, А. Новіков, Г. Селевко, В. Хутмахер, А. Хуторський, О. Чуракова та ін.) показав, що нині розходяться думки науковців щодо співвідношення цих категорій, їх класифікації та видів.

Водночас одним із першорядних завдань теоретичного обгрунтування компетентнісного підходу є визначення понять і термінів. У наукових публікаціях про компетентнісний підхід найважливішими термінами $€$ «компетентність», «компетенція». Необхідно визначити кожен із них.

У Великому тлумачному словнику сучасної української мови знаходимо такі визначення вищезазначених понять: компетентність походить від латинського слова «competens» (competentic), що в перекладі означає належний, здібний. Компетентність це певна сукупність знань в особи, які дозволяють їй судити про що-небудь, висловлювати переконливу, авторитетну думку. Компетентний - це той, хто знає, обізнаний у певній галузі; який має право за своїми знаннями або повноваженнями робити або вирішувати що-небудь, судити про що-небудь [1, с. 445].

У педагогічному словнику слово «компетентність»- це здатність фахівця застосовувати знання для вирішення практичних завдань відповідно до його компетенції, тобто колом повноважень, професійних обов'язків, питань, у яких певна людина достатньо обізнана, володіє необхідною інформацією та практичним досвідом [10, с. 17].

Передбачається, що компетентність - це здатність до практичної діяльності та розв'язання життєвих проблем на основі набутого студентами (учнями) навчального і життєвого досвіду та відповідних цінностях [5, с. 11].

Російська дослідниця Л. Мітіна вважає, що поняття «педагогічна компетентність» охоплює знання, вміння, навички, а також способи і прийоми їх реалізації в діяльності, спілкуванні, розвиткові (саморозвиткові) особистості» [5, с. 46].

В. Сластьонін визначає професійну компетентність як інтегральну характеристику ділових і особистісних якостей спеціаліста, яка відображає не тільки рівень знань, умінь i досвіду, достатніх для досягнення цілей професійної діяльності, а й соціальноморальну позицію особистості. У понятті «професійна компетентність» науковець виокремлює три аспекти: проблемно-практичний, смисловий та ціннісний. Різновидами професійної компетентності $\quad$ В. Сластьонін уважає такі: практична (спеціальна), соціальна, психологічна, інформаційна, комунікативна, екологічна, валеологічна [9, с. 34-35].

У дослідженні В. Нестеренко вивчається професійно-валеологічна компетентність як складник загальної професійної компетентності майбутнього педагога, яка 
конкретизує його теоретичну i практичну підготовку щодо розв'язання питань, пов' язаних з вихованням у дошкільників навичок здорового способу життя [7].

I. Зимняя, розглядаючи єдину соціально-професійну компетентність випускників вищих навчальних закладів, відносить компетентність здоров'язбереження до групи компетентностей людини як особистості, суб' єкта діяльності та спілкування. При цьому компетентність здоров'язбереження, на думку науковця, охоплює: знання та дотримання норм здорового способу життя, знання небезпеки паління, алкоголізму, наркоманії, СНІДу; знання і дотримання правил особистої гігієни, побуту; фізичну культура людини, свободу і відповідальність вибору способу життя [3, с. 14-19].

Здоров'язберігальну компетентність педагога, 3 погляду О. Шатрової, потрібно розглядати як інтегральну якість особистості, побудовану на інтеграції знань, умінь і досвіду, що виявляється в загальній здатності і готовності до здоров'язберігальної діяльності в освітньому середовищі [15].

Узагальнюючи позиції вітчизняних і зарубіжних дослідників, ми пропонуємо таке трактування поняття здоров'язберігальної компетентності майбутнього вчителя. Здоров'язберігальна компетентність майбутнього вчителя початкових класів - це система знань і уявлень про позитивні і негативні зміни в стані власного здоров'я та здоров'я оточуючих; вміння скласти дієву програму збереження свого здоров'я i здоров'я учнів в умовах навчально-виховного процесу; вміння створювати і розвивати здоров'язберігальне освітнє середовище; володіння способами організації діяльності 3 профілактики здоров'я та здоров'язбереження; володіння освітніми технологіями, що сприяють збереженню здоров'я учнів; вміння досліджувати ефективність освітнього процесу з питань здоров'язбереження, а також здатність організувати і реалізувати діяльність $з$ профілактики та здоров'язбереження.

Формування здоров'язберігальної компетентності педагогів передбачає виявлення ii структурних складників. У структурі здоров'язберігальної компетентності О. Югова [14] пропонує виокремити змістовний, діяльнісний та особистісний компоненти.

Перший компонент передбачає наявність у студента знань 3 конкретної дисципліни, а також $з$ суміжних дисциплін, що виражає квінтесенцію спеціальності (концептуальна компетентність), якою має оволодіти студент.

Структура концептуальної компетентності визначається, виходячи 3 таких міркувань. Знання будь-якого питання для фахівця не може бути недостатнім, оскільки на основі таких знань не можна прийняти рішення, тобто виявити свою компетентність. Знання за своєю суттю є комплексними, неподільними й окремі розрізнені уявлення не можуть утворити системи знань. Знання не стане інтегративним, якщо його компоненти вивчалися окремо. Інтегративність повинні забезпечити викладачі, які працюють у взаємодії зі студентами. Такий алгоритм забезпечує абсолютно іншу якість знань, оскільки в умовах інтегративного навчання виробляються асоціативні зв'язки, які переважно і характеризують якість знань. Тобто визначаємо об'єктивну необхідність кооперувати зусилля багатьох викладачів, які так чи інакше задіяні у формуванні здоров'язберігальної компетентності. Прикладом можуть слугувати дисципліни, що послідовно вивчаються: вікова анатомія і фізіологія, за ними - основи медичних знань (або основи педіатрії та гігієна), завершує формування компетентності дисципліна безпека життєдіяльності.

Другий, діяльнісний компонент, охоплює інваріантні професійні здоров’язберігальні практичні вміння (володіння). Сюди відноситься весь комплекс практико-орієнтованих занять (семінарські заняття, лабораторний практикум, практичні заняття, розв' язання ситуаційних задач, ділові та рольові ігри тощо). 
Третій, особистісний компонент, охоплює інтегративні особистісні якості, тобто наявність вроджених здібностей до навчання та вміння самостійно здобувати знання, тобто самостійно працювати з науковою та навчальною літературою (писати реферати, доповіді, брати участь у науково-дослідній роботі тощо). Студент повинен володіти не просто певним видом інтелекту, а вміти користуватися ним відповідно до конкретної ситуації.

O. Шатрова пропонує чотирикомпоненту структуру здоров'язберігальної компетентності педагога: ціннісно- мотиваційний компонент, когнітивний компонент, операціонально-технологічний компонент та компонент особистісних і професійнозначущих якостей педагога [15].

На основі аналізу компонентів структури компетентності, поданних у науковій літературі [3; 5; 14; 15], ми пропонуємо таку структуру здоров'язберігальної компетентності майбутнього вчителя початкових класів, яка містить такі компоненти:

- ціннісно-мотиваційний, що становить систему цінностей педагога (головна цінність - здоров'я), що мотивують його на здійснення здоров'язберігальної діяльності, виявлясться в інтересі і потребах педагога до формування здоров'язберігальної компетентності;

- когнітивний, що передбачає наявність системи знань 3 педагогічних та суміжних дисциплін; знання про закономірності збереження і розвитку здоров'я, прагнення до самоосвіти в питаннях здоров' язбереження;

- операціонально-технологічний, який передбачає оволодіння майбутніми вчителями початкової освіти вміннями здійснювати здоров'язберігальну діяльність, реалізовувати поведінкові моделі здорового способу життя, використовувати здоров'язберігальні технології та удосконалювати власне здоров'я;

- особистісно-етичний компонент, який охоплює: почуття громадянської відповідальності за збереження і зміцнення власного здоров'я і здоров'я учнів, гуманізм, щиросердя, уважність, доброзичливість, дисциплінованість, вимогливість до себе, принциповість, скромність, об'єктивність, самокритичність, високу моральну культуру, терпеливість і наполегливість.

- професійно-педагогічний компонент, який містить: високий рівень професійнопедагогічної підготовки, інтерес до педагогічної діяльності, любов до справи і дітей, педагогічний такт, педагогічне мислення, професійно педагогічну працездатність, тактовність, емпатію, толерантність, рефлексію тощо.

Компоненти структури здоров'язберігальної компетентності педагога $\epsilon$ взаємопов'язаними і динамічними, оскільки означає компетентність не є усталеним поняттям, і кожна конкретна ситуація вимагає певних здібностей, якостей особистості та готовності до здійснення здоров'язберігальної діяльності.

Формування в майбутніх учителів початкових класів вищезазначених компонентів здоров'язберігальної компетентності i підтвердження готовності педагогів до здійснення здоров'язберігальної діяльності, зумовлює необхідність чітко уявляти зміст та структуру необхідних для цього компетенцій.

Зміст здоров'язберігальної компетенції, насамперед, визначається тими дидактичними одиницями, які визначає робоча навчальна програма дисципліни, на основі $з$ якої розробляється повний навчально-методичний комплекс дисципліни, спрямований на формування цієї компетенції. Незважаючи на відмінності у назвах навчальних дисциплін, у різних стандартах є єдина інваріантний складник, яка об'єднує цей комплекс дисциплін. Передесім, це питання, пов'язані з онтогенезом, віковими особливостями будови і перебігу фізіологічних процесів, а також гігієни дітей та підлітків [14]. 
Формування здоров'язберігальної компетентності в майбутніх учителів початкових класів передбачає виконання таких умов:

1. Компетентність повинна формуватися фахівцями в певній галузі знань, які мають базову спеціальну освіту (медичну або біологічну) і проводять наукові дослідження за профілем дисципліни, яку вони читають.

2. Структура здоров'язберігальної компетентності повинна бути інтегративною i реалізовуватися через комплекс взаємопов'язаних дисциплін медико-біологічного циклу, об'єднаних загальним смисловим навантаженням.

3. Зміст здоров'язберігальної компетентності має співвідноситися 3 загальнокультурними і професійними компетенціями, виокремленими в державному освітньому стандарті за фахом [14].

Отже, можна вважати, що сформована здоров'язберігальна компетентність майбутнього вчителя початкових класів забезпечить його здатність розуміти, пояснювати, регулювати свій функціональний стан, поведінку, спосіб життя задля збереження власного здоров'я та здоров'я учнів, а головне - покращення якості життя й довкілля.

Здоров'язберігальна компетентність майбутніх учителів 3 початкової освіти орієнтує їх на відповідальне ставлення до власного здоров'я та здоров'я учнів, формування в навчально-виховному процесі здоров' язберігальної компетентності учнів, упровадження в освітній процес педагогічних технологій, що сприяють формуванню навичок здоров'язберігальної поведінки, як основи здорового способу життя, а також розвиток психологічної культури, комунікативних здібностей і навичок саморегуляції педагогів.

Проведене дослідження не вичерпує проблеми формування здоров'язберігальної компетентності майбутніх педагогів. Доцільним $є$ дослідження організаційнопедагогічних умов і системи формування здоров'язберігальної компетентності майбутніх педагогів тощо.

\section{Література}

1. Великий тлумачний словник сучасної української мови / уклад. і голов. ред. В. Т. Бусел. - К. ; Ірпінь: ВТФ «Перун», 2004. - 1440 с. 2. Влияние социальных факторов на здоровье и аддиктивное поведение студентов/ Л. Н. Коробов, А. Н. Карзаков,

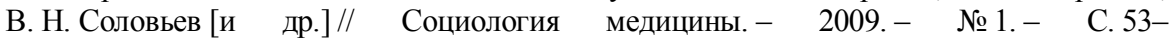
59. 3. Зимняя И. А. Интегративный подход к оценке единой социальнопрофессиональной компетентности выпускников вузов / И. А. Зимняя, Е. В. Земцова // Высшее образование сегодня. - 2008. - № 5. - С. 14-19. 4. Кострова Ю. С. Генезис понятий «компетенция» и «компетентность»// Молодой ученый. - 2011. - № 12. С. 102-104. 5. Митина М. Л. Психология профессионального развития / М. Л. Митина. - М., 1998. 6. Національна стратегія розвитку освіти в Україні на період до 2021 року [ Електронний ресурс] - Режим доступу: http:/president.gov.ua/documents/ 15828.html. 7. Нестеренко В. В. Підготовка майбутніх педагогів до виховання у дошкільників навичок здорового способу життя: автореф. дис. на здобуття наук. ступеня канд. пед. наук / В. В. Нестеренко; ПДПУ імені К. Д. Ушинського. - Одеса, 2003. - 20 с. 8. Панчук Н. С. Проблема формирования здоровьесберегающей ответственности студентов в современном вузе/ Н. С. Панчук, Н. А. Шмыгрева// Ученые записки университета им. П.Ф. Лесгафта. - 2011. - № 1 (71). - С. 87-90. 9. Педагогика профессионального образования / под ред. В. А. Сластенина. - М. : Издательский центр «Академия», 2004. - 368 с. 10. Педагогический энциклопедический словарь. - М. : Большая российская энциклопедия, 2002. 11. Попов А. А. Модель организации здорового образа жизни студентов в творческом вузе / А. А. Попов // Вестник 
Кемеровского государственного университета культуры и искусств. - 2011. - № 14. С. 57-67. 12. Проскурякова Л. А. Здоровьесбережение в системе высшего образования / Л. А. Проскурякова // Высшее образование сегодня. - 2010. - № 6. С. 80-83. 13. Селезнева Н. А. К вопросу о социально-психологической адаптации студентов к условиям учебной работы в вузе/ Н. А. Селезнева // Ученые записки Казанской государственной академии ветеринарной медицины им. Н. Э. Баумана. 2010. - № 202. - С. 331-336. 14. Югова Е. А. Технологии формирования здоровьесберегающей компетентности у студентов: [монографія]/ Е. А Югова; рец.: С. Г. Махнева, Л. Г. Петрова; Рос. гос. проф.-пед. ун-т. - Екатеринбург: Издательство РГППУ, 2012. - 116 с. 15. Шатрова Е. А. Моделирование здоровьесберегающей компетентности педагога/ Межвуз. науч. конф.-семинар молодых ученых по результатам исследований в области психологии, педагогики и социологии (25 декабря 2009 г., г. Красноярск): сб. тр.: в 3 ч. Ч.3. / под общ. ред. Я. А. Максимова; Научноинновационный центр - Красноярск, 2010. С. 124. 16. Устав (Конституция) Всемирной Организации Здравоохранения// ВОЗ. Основные документы. 39-е издание; [пер. с англ.] - М. : Медицина, 1995. - 208 с.

УДК 378.147:371.38.

Віктор Мадзігон

\section{ТЕОРЕТИКО-МЕТОДИЧНІ ЗАСАДИ ПІДГОТОВКИ ПІДПРИЕМЦІВ У СИСТЕМІ ЕКОНОМІЧНОЇ ОСВІТИ}

Мадзігон В. В. Теоретико-методичні засади підготовки підприємців у системі економічної освіти.

У статті висвітлюється актуальна проблема необхідності на сучасному етапі підготовки підприємців у системі безперервної економічної освіти, у навчанні учнівської та студентської молоді. Набуті знання 3 економічних дисциплін вони зможуть використовувати у практичній діяльності на ринку праці в різних галузях суспільних потреб задля піднесення добробуту держави й суспільства.

Ключові слова: ринкова економіка, економічна освіта, підприємництво, підприємці, фахова компетентність, ринок праці.

Мадзигон В. В. Теоретико-методические основы подготовки предпри-нимателей в системе экономического образования.

В статье освещается актуальная проблема необходимости на современном этапе подготовки предпринимателей в системе непрерывного экономического образования, в обучении школьников и студенческой молодежи. Приобретенные знания экономических дисциплин они смогут использовать в практической деятельности на рынке труда в различных отраслях общественных потребностей для повышения благосостояния государства и общества.

Ключевые слова: рыночная экономика, экономическое образование, предпринимательство, предприниматели, профессиональная компетентность, рынок труда.

Madzygon V. V. Theoretical and methodological basis of training of entrepreneurs in the system of economical education.

The article observe an important issue of current interest of the necessity of training of entrepreneurs in the system of continuous economical education, of education of students; 